\title{
ROS1 Rearrangement Testing Method
}

National Cancer Institute

\section{Source}

National Cancer Institute. ROS1 Rearrangement Testing Method. NCI Thesaurus. Code C158953.

A request to enter the specific molecular analysis method used to detect and identify rearrangements involving the ROS1 gene. 